\title{
JESUS AND THE GENTILE MISSION
}

\begin{tabular}{ll} 
Mr. A.J.Smiles* & $\begin{array}{l}\text { M.div Student At Coach Institute Of Intercultural Studies, Hyderabad. } \\
{ }^{*} \text { Corresponding Author }\end{array}$ \\
\hline $\begin{array}{l}\text { Prof. Potana } \\
\text { Venkateswara Rao }\end{array}$ & Phd. Director, Coach Institute Of Intercultural Studies, Hyderabad \\
\hline
\end{tabular}

ABSTRACT Christian faith has a significant role to play with its neighbors and people of other faiths. Jesus Christ was gentle and relational in his approach to the people of other faiths during his life and ministry. In fact, his disciples also maintained that positive relationship in their mission praxis; but in these days there is a lot of tension that can be seen in Christian Mission praxis in their approach to the people of other faiths. In this context this research article attempts to show Jesus' objective understanding of Gentiles with an aim to help the reader to maintain positive relationship with people of other faiths.

KEYWORDS : Jesus, Gentile, Mission, Christ, Jews, Eschatology

1.Introduction

Jesus Christ, the Son of God, incarnated into this world with an aim to save the lost and restore the broken relationship between God and Man. In His mission praxis, Jesus was neither critical nor judgmental towards people of other faiths but rather He was relational and appreciative of the gentiles. The paper addressees questions such as what was Christ's relationship and attitude toward Gentiles (the non-Jewish people)? Does He relate His ministry to the world of nations? Was Christ a nationalist, particularist, or was he a Universalist? Were the benefits of His life and death mean to only for the Israelites or for the entire human beings of the world? Was Jesus in his days on the earth as a human being, conscious of His racial significance and of a universal mission? Did He have a plan to reach out to the Gentiles worldwide? In fact various scholars have argued that Jesus did not sanction a Gentile mission and some other argued that that He had preferential option for the Gentiles.

Present day Christianity would answer the last question positively, as we see today's Christianity worldwide is substantially made up of peoples from all over the world, and thus accept that the universality of Christianity and Jesus. However, this is the most researched, debated and commented in Mission Theology. Dr. Samuel Zwemer summarize four historic views: The first is the extreme view of Hegel, Tolstoi and others that Jesus was anti-Semitic and conscious only of a universal mission! The exact opposite view is that Jesus was at heart a Jew and limited His horizon and message to the house of Israel. Reimarus, Strauss, Wellhausen, and Harnack are representatives of this other radical view and they have had many followers. A third school of critics says that Jesus was at first narrow and Jewish and that only toward the end of His life did He become conscious of a world-mission (Keim, Hausrath, Bertholet, Bernard Weiss). Against all of these radical views is the traditional one held by believing scholars, Roman Catholics, and Protestant - namely, that Jesus from the outset of His ministry had a view of humanity as a whole, but felt that He was sent especially to the lost sheep of the house of Israel, and that His earthly ministry was mainly to the people of Israel.

In the context of these different views, the purpose of this paper is an evaluation of the diverse perspectives, opinions and approaches to the study of Jesus and the Gentiles Mission.

2.Challenges in establishing Jesus and Gentile Mission a.Christianity originated among Jews
It is remarkable to note that several facts of Jewish predominance in the origin of Christianity. Jesus was a Jew and all his apostles were also Jews. Jesus is reported in the Gospels that he has come for His people, Jews. In fact, Apostle Paul also specifically limiting his ministry to Israel (Mat 10: 5-6, 15-24, Rom 15: 8). Jesus initially called his disciples only to Gentile Territories. There are only few instances where Jesus purportedly had contacts with Gentiles. The First Christian Leaders are all Jews. The movement originated not in the Jewish Diaspora but in the heart of Palestine. Early Christians had mixed views about inclusion of gentiles in their ranks. Did this idea of Gentiles mission originate from the teachings of Jesus himself? This is indeed the question.

\section{b.Jesus and the Gentiles relationship}

Jesus relationship with the Gentiles is the most challenging question for the researchers and students missiology. During the lifetime of Jesus, Gentiles very rarely encountered Him. The most fascinating question then is how and why so immediately after his death did the Jesus movement come to see the Gentiles inclusion as a natural extension of itself? The current consensus would probably say no. Indeed one of the most prominent answers from Joachim Jeremias is that 'Jesus believed that the Gentiles would be saved by God at the eschaton and without recourse to any mission agency. The Great Commission of Mat $28: 19-20$ is an utterance of the risen Christ and speaks to a post-Easter situation, and the same is true of Luke 24:47 and Acts 1:8."

c.Jesus' purported negative comments about Gentiles :

Some of the most critical questions and comments about the attitude of Jesus towards Gentiles arise predominantly from a handful of Bible verses.

1. Syrophoenician woman (Mk 7: 24-30; Matt. 15: 21-8) "First let the children eat all they want," he told her, "for it is not right to take the children's bread and toss it to the dogs."

2. Matthew 10;5 "These twelve Jesus sent out with the following instructions: "Do not go among the Gentiles or enter any town of the Samaritans".

3. Matthew $15 ; 24$, "Then Jesus said to the woman, "I was sent only to help God's lost sheep-the people of Israel." is also used by some critics, to say that Jesus does not have anything to do with Gentiles.

4. Mark 10:5-6 is another most heatedly debated section: "These twelve Jesus sent out with the following instructions: "Do not go among the Gentiles or enter any town of the Samaritans. Go rather to the lost sheep of Israel". 
d.Apostle Paul's failure to cite Jesus' Gentiles Mission:

Paul's failure to cite sayings of Jesus concerning the legitimacy of the Gentile mission is not entirely unexpected or even inexplicable. Situation of Pauls' readers did not require the Gentiles mission to be legitimized.

\section{e.Apocalyptic writings and Rabbinic Tradition:}

In apocalyptic writings and the Qumran literature there is no evidence for the idea of winning over the Gentiles; the opposite hope, namely for their destruction, is far more prominent. Even in the rabbinic tradition, for example among the Shammaites, a negative attitude is found.The Jewish approach to the heathen was basically a matter of private enterprise undertaken by individuals; it did not spring from $a$ belief that the community as a whole had a responsibility for all mankind

\section{UNIVERSALITY OF JESUS CHRIST AND THE CHRISTIANITY}

a. Despite all these challenges, Christianity found impetus within itself , to found gentile religious communities and to include them under the name of "The Israel of God"

b. God's purpose from the beginning of the biblical story has been to restore the entire creation, including the whole of human life from all nations, from the dreadful effects of sin. But God's people, Israel, failed in their task: instead of being a model to the people, they become like other nations, polluted by idolatry. They are then scattered all over the world in Judgement. With the coming of Jesus, the promised gathering of God's eschatological people begins. In Jesus, we see God's 'eschatological action' to restore or even re-establish his people, in order to carry out definitively, and irrevocably his plan of having a holy people in the midst of nations

c. Paul's epistles and Book of Acts make it clear that the Pauline mission was the response to Paul's "Damascus Road" experience. According to Galatians , Paul's gospel, the revelation of preaching to the Gentiles, and his apostleship are conferred directly by the exalted Lord Jesus and not mediated via Jerusalem Pillars ( Gal l : 11 to 2: 10).

d. Then, a mission to gentiles was never disputed. It was only the admission of Gentiles into the Church that was disputed.

e. Although Jesus was not the founder of Christianity, rapid emergence of Gentiles mission in early Christianity, raises the question of continuity between Jesus and his early followers concerning Gentiles mission.

f. First Jewish Christian Hellenists (Greek Christians) preached to Gentiles in Antioch sometime in the mid 30's $\mathrm{CE}$ (Common Era or BC) ten years or more prior to Paul's first missionary journey. Paul's zeal in persecuting the Church ( Phil 3:9 , Gal 1:14, Cor 15:9) was aimed principally against Jewish Hellenistic Christians who had crossed the Jew-Gentile divide. Thus the Paul's zeal in persecuting the Church presupposes the existence of the Jew-Gentile interaction of the type reported in Antioch.

g. Luke projected the story of the Hellenists at Antioch (Acts $11: 19-21$, Acts $8: 1-5$ ) to a later points in Acts in order to prioritize Paul's conversion (Acts 9:1-30) and Peter's conversion of Cornelius (Acts $10: 1-11,18$ ). This seems plausible given that Acts 9:1-11,18) interrupts a continuous account of a Hellenistic mission. The reason for this insertion by Luke is probably to attribute the Gentile breakthrough to Peter, to give the Gentile mission apostolic precedent and to introduce Paul prior to the
Cornelius narrative.

\section{JESUS AND THE GENTILES MISSION}

5.1Failed Expectations: Some scholars argue that the emergence of the Gentiles mission was a result of failed expectations in the primitive church. Bosch states 'It is not true that, in the early church, mission gradually replaced the expectation of the end. Rather mission was, in itself, an eschatological event.

5.2Delay and Dispute of Gentile Mission: Another argument is that (1) the delay and dispute of Gentiles mission in the early church makes it difficult to agree that Jesus spoke of a future Gentiles mission. (2)They also argue that the mission was conducted by Hellenists (Diaspora Jews who spoke Greek) such as Paul and Barnabas and not by the 12 disciples of Jesus. (3)Also the dispute in the early church was not simply about the basis of Gentiles entrance, but rested on a far more fundamental conviction that the Gentiles would not partake in salvation until the eschaton.

(1)The delay is explainable by the fact, that it took the early Christians movement some time to organize itself, after Jesus death. Point (2) is because of the division of responsibilities of ministrations to the Jews divided between the Apostles. It is speculated that, when Paul only finds in Jerusalem three pillars (James, Peter and John ), the absence of the other initial followers of Jesus is due to the fact that they were preaching and healing in Palestine, in accordance with Jesus commands elsewhere ( Mark 13;14 ) . Point (3) Scenario of initial resistance was followed by acceptance of the Gentiles is found in the reverse order in Acts. In Acts it is only after the mission is underway that Jewish scruples are offended. Even Christian Judaizers wanted to win over Gentiles, as is evident from Gal 6:13, and Acts 15:5.

\subsection{What do Biblical Researchers say?}

The various researchers of Jesus and the Gentiles mission are broadly classified to two categories. First category who argue that Jesus did not sanction a Gentile mission and those who argue that he did.

a) Scholarship Prior to Jeremias: Early $20^{\text {th }}$ century scholarship wrestled with the question of Jesus and the Gentile Ministry. Adolf von Harnack and Maurice Goguel, stated that Jesus had no ambition for the salvation of the Gentiles. Goguel perceives in Jesus at most a "germ of universalism" while Harnack believes that Jesus spoke of a love of God and men, which may be described as an implicit universalism. In contrast Friedrich Spitta viewed Jesus as a Universalist. According to Spitta, Jesus was open to the Gentiles due to his origins in the Gentile populated region of Galilee and Spitta sees Jesus as consciously trying to close the division between Jews and Gentiles. In Scheweitzer's estimation, Jesus is a universalistic in His thinking and Jewish -particularistic in His action.

b)Joachim Jeremias's study: Jeremias (1900-1979) a German Theologian, scholar of Near Eastern Studies and university professor for New Testament studies.His study, 'Jesus Promise to the Nations" has significantly impacted scholarly estimations of Jesus' view of Gentiles. Jeremias study, still commands even now wide respect and acceptance in many quarters of New Testament studies, even after more than 60 years. Jeremias commences his work by making three negative conclusions. First Jesus pronounced a stern judgement upon the existing Jewish mission. Second Jesus forbade his disciples during his lifetime to preach to non-Jews. Third Jesus limited his own activity to Israel.

Jeremias then offers three positive conclusions. First, Jesus removes the idea of vengeance from eschatological 
expectation(Luke 4:16-30). Second, Jesus promises the Gentiles a share in eschatological salvation (eg. Mat 8: 11-12). Continued resistance to Jesus' message would result in Israel being excluded and Gentiles being included in God's saving designs. Third the redemptive activity and lordship of Jesus include the Gentiles. According to Jeremias, the message of salvation offered to the Gentiles by Jesus is incomprehensible unless we realize that it is based on Jesus' consciousness of authority. His view primarily suggests Gentiles as being saved by God at the eschaton.

Jeremias boldly claims that "the only significance of the whole of Jesus activity is to gather the eschatological people of God.

5.4Jewish Restoration Eschatology : Broadly defined, 'Jewish restoration eschatology' is the belief that God would intervene and establish a better dispensation for Israel in light of circumstances that did not reflect the grand promises of peace and prosperity pledged in Israel's sacred traditions. This hope was predominantly a consequence of the post-exilic conditions, in which many Jewish people were either dispersed away from their homeland or ruled by foreign overlords. Among the general hopes was the notion that the Gentiles would simply acknowledge God was God, and would give him praise. Elsewhere one finds expectation that the Gentiles would accept Torah, which was meant to be a light of nations. It was also conceivable for God's grace to embrace the Gentiles.

a)Analysis of Jesus Restoration Eschatology : Michael F. Bird suggests that Jesus invokes the view of the salvation of Gentiles in relation to the Jewish story. E. P. Sanders remains largely responsible for popularizing the view of Jesus as a prophet in the tradition of Jewish restoration eschatology. Jesus intention was to renew and restore Israel, so that a restored Israel would extend God's salvation to the world. Since this restoration was already being realised in Jesus Ministry, it was becoming possible for Gentiles to share in the benefits of Israel's restoration. Furthermore, Jesus understood himself and his followers as the initiators of the new temple and the restored Israel who would appropriate for themselves the mission of Israel and the temple in being a light to the nations. Hence a Gentile mission is implied in the aims and intentions of Jesus and was pursued in a transformed context by members of the early Christian movement.

Jesus advocated a particular type of Jewish restoration eschatology, which held that the Gentiles would be saved as a sequel to the restoration of Israel. Jesus negative remarks about Gentiles and the statements that restrict his ministry to Israel do not negate in the Gentiles via the link of Restoration eschatology. There are materials and narratives, that show that Jesus advocated a view of this restoration as partially realized (Mark 1:15, Luke 4:21) and as pointing to the inclusion of the Gentiles in God's salvific design. Jesus says to the Pharisees: "But if it is by the Spirit of God that I drive out demons, then the kingdom of God has come upon you" (Matt. 12:28).Basis of the future Gentiles missions rests on the mission of the disciples in approximating and appropriating the role of Israel and the temple as a light of nations. The power of God in Jesus challenges the unjust structures and the idolatrous orders of both Jewish and Roman cultures. For example, Jesus confronts the way exclusivist nationalism has corrupted Israel; he insists on including the marginalized and disenfranchised in his ministry

b)Imminence of Eschatology or Delay? Imminence of the eschatology or is there any intervening period is the biggest question? The imminence must be understood in conjunction with complexes in which Jesus entertains the possibility of its delay. (1) The testing (Luke 11.4 / Mat 6:13 ) has not yet occurred, (2) Persecution and witnessing (Mark 8:35-38 , Mat
10:16-25 , Lk 11:49, 21:13) imply further periods of activity (3) the parable of unjust judge (Luke 18:7) contemplates the prospect of postponement (4) Jesus refusal to drink from the "fruit of the vine" until the kingdom comes in its fullness (Mark 14:25, Mat 26: 29, Luke 22:18) and his apparent ignorance of the timing of the end (Mark 13;32, Mat 24:36) may also be indicative of an interval of some kind. Similarly the parables of growth (Mark 4:26-32, Mat 13;31-32, Luke 13:18-19), the possibility of time being cut short (Mark 13; 20, Mat 24:22 ), and the parable of ten talents, in which nobleman goes to a distant country to become king (Luke 19: 11-27) may be taken to involve some notion of delay. It remains wholly possible that such an interim period could be filled with the existence of an eschatological community founded by Jesus with an authorized mission to Jews and the Gentiles from Jesus.

c)Scholar's views on Jewish Restoration Eschatology : First, Jesus' gospel of the kingdom arguably has overtones of restoration theology. Second Jesus' calling of twelve disciples provides a further indication of his intention to restore Israel. The calling of twelve tribes and the material concerning the mission of Jesus and his disciples to Israel (Mat 10:5-6, 15: 24) strongly implies a concern to restore Israel. Several scholars have proposed that Jesus sought to create a remnant within Israel and not trying to reform all Israel. Thus Jesus' particular brand of restoration eschatology is perhaps best described as symbolic restoration.Michael F. Bird argues that there is a link between Jewish restoration eschatology and the salvation of Gentiles, and that Jesus was a proponent of particular brand of Jewish restoration eschatology.

\section{EVIDENCE}

Let us now, examine some evidences, which support that Universality and Gentiles Mission of Jesus.

6.1 People from the west \& east all coming for the messianic Feast mentioned in Matt. 8: 11 and Lk. 13: 29we see the Gentiles blessed

6.2 Second, comparison between Jonah and Jesus Gentilemission to be found in Matt. 12: 39, Lk. 11: 29, as referring to their preaching of repentance in the face of impending doom.

6.3 Third, there is the parable of the sheep and the goats (Matt. 25: 31-46).

6.4 Fourth,Manson and Jeremias also see a reference to the Gentiles in the parable of the mustard seed (Mk 4: 30-2 pars.) in the reference to birds, since in Jewish literature birds can mean Gentiles (Ps. 104: 2; I En. 90: 33).

6.5 R. Liechtenhahn thinks Mk 14: 24 signifies the hour when the Gentile mission was born, in that now the proclamation to the Gentiles, in a historical sense, can begin.

6.6 Even the story of the Syrophoenician woman (Mk 7: 24-30; Matt. 15: 21-8) and negativity sown here is considered to be linguistic corruption and the Mark's Aramaic diminutive wording by many scholars including, Bosch, Jeremias, Hahn etc.

6.7 We can include here two other incidents in which Jesus apparently heals a Gentile, namely the Gadarene demoniac (Mk 5: 1-20 pars.)6 and the centurion's son (Matt. 8: 5-13; Lk. 7:I-IO).

6.8 We have offered several negative observations on these miracle stories in order to counteract any attempt to overrate their significance, but now we must consider their positive value. F. Hahn is at pains to show, on the basis of Lk. 11: 20 par., that these narratives signify a very real access to the kingdom of God for the Gentiles, for in these and in any other miracles the kingdom of God is realised.

6.9 Jesus himself could have seen this and yet still have maintained a basically futuristic hope for the Gentiles which would be fulfilled in the final, manifest in breaking of the kingdom.

6.10Spitta thought that from the very beginning Jesus 
intended to promote the Gentile mission, an intention which clashed with the typical outlook of the Pharisees. Jesus, therefore, can be regarded as the first Christian missionary, and sayings such as those found in Matt. 10: 5$6,23,15: 24$ cannot be attributed to him

6.11 Hahn, while also rejecting $\mathrm{Mk}$ 13: 10, 14:9, similarly rejects the particularist sayings on the grounds that in the authentic tradition Jesus was open to the Gentiles.

6.12Even though some scholars see a contradiction between Mat 10;23 and Mark 13;10, Bosch says, 'We must therefore regard Matt. 10: 23 as an independent word of Jesus which, by analogy with the saying about the Gentile mission $\mathrm{Mk}$ 13: 10, expects a Jewish mission during the whole period between the Resurrection and the Parousia .

6.13Jesus frequently condemns Israel for failing to repent and, more significantly, the fact that he frequently connects the Jews' obduracy with the future inclusion of the Gentiles (Mk:15-17, 12: 1-9; Matt. 8: 11, 10)

\section{CONCLUSION}

The question of Jesus approach to the Gentiles is yet another acute problem for the historical theologian. In looking over the literature, theologies, and social history of early Christians, significant problems are involved in attempting to attribute any view of the Gentile mission to Jesus, and on the other hand, evidence implying that it is in fact possible to attribute the Gentiles mission to Jesus.

a. Jesus limited himself, in his earthly ministry, to Israel to certain extent and commanded his disciples to do likewise on couple of occasions.

b. Nevertheless, according to Jesus' teaching the Gentiles have a definite place in the kingdom of God

c. The link between the Gentiles and the kingdom of God is frequently made in a context where Jesus appears to have thought that this kingdom was imminent

d. On exceptional occasions Jesus responded, though with considerable reluctance, to certain Gentiles who persistently appealed to him

I would like to reemphasize here in conclusion that God has limited our ability to understand scriptural prophecy; deep humility is needed to approach and unfold it.Given these shortcomings, I would like to again like to refer back to some important Bible verses that prove Jesus Universality and Gentiles mission.

i. Prophecy in Old Testament through Isaiah $11 ; 10:$ In that day the Root of Jesse will stand as a banner for the peoples; the nations will rally to him, and his resting place will be glorious" defends Jesus's universality and Gentiles mission. We see the fulfilment through John 12:18-21.

ii. Mt 28:16-20 is crystal clear with regard to God's intentionall nations have to be exposed to the message of the gospel so that Jesus would have disciples from all nations.

iii. The prophecy that Jesus would draw the Gentiles to himself (Isaiah 11; 10) "In that day the Root of Jesse will stand as a banner for the peoples; the nations will rally to him, and his resting place will be glorious", is fulfilled through Mark 1;14, by Jesus starting mission in Galilee a predominantly Gentiles location.

iv. Matthew 24:14 - "This gospel of the kingdom shall be preached in the whole world as a testimony to all the nations, and then the end will come" are the words spoken by Jesus himself directly to his disciples.

v. After his resurrection, Jesus reaffirmed to his disciples through Great Commission, in Mark 16:15-16 - "And He said to them, 'Go into all the world and preach the gospel to all creation. He who has believed and has been baptized shall be saved; but he who has disbelieved shall be condemned."

I believe in what Jeremias asserts that Jesus's roles as the Son of Man, Messiah, Son of David and Servant of Yahweh all imply a certain relationship to the Gentiles as ruler and saviour. The promise for the Gentiles is therefore wholly bound up with the fact that Jesus is the fulfiller of scripture. Lastly I would like to mention that "let your faith roar so loud that you can't hear what doubt is saying.

\section{REFERENCES}

1. George W. Peters, A biblical theology of missions (Chicago: Moody Publishers, 1984), 36

2. Michael F. Bird, Jesus and the Origins of the Gentile Mission (New York; Bloomsbury Publishing, 2006), 3 .

3. Gerhard Lohfink, Jesus and Community: The Social Dimension of the Christian Faith (Philadelphia: Fortress Press , 1982), 123.

4. John G. Gagar, Kingdom and community : The social world of early Christianity (New Jersey: Prentice-Hall, 1975), 38

5. David Bosch, Transforming Mission: Paradigm Shifts in Theology of Mission (New York; Maryknoll 1991), 41.

6. Gerd Theissen, Sociology of Early Palestinian Christianity (Philadelphia Fortress Press, 1978) 9

7. Maurice Goguel, The Life of Jesus (London: Allen \&Unwin, 1954), 323

8. Harnack, Expansion of Christianity, 45.

9. Friedrich Spitta, Jesus und die Heidenmission (Giessen, Alread Topelmann 1909),72.

10. Albert Schweitzer, The Mysticism of Paul the Apostle (Baltimore: John Hopkins University Press, 1998), 180

11. Jeremias, Promise, 11-19

12. Jeremias, Promise, 19-25

3. Jeremias, Promise, $25-39$

14. Jeremias, Promise, $41-46$

15. Jeremias, Promise, 46-51

16. Jeremias, Promise, $51-54$

17. Dan 3:28-29, 4;1-37, 6;26-28, Pss 66. 1-20, 22-27, 46;10, 96 :7-10, 117 : 1-2, Ezek 39;7, 2 Macc 3:28

18. Michael F Bird, Jesus and the Origins of the Gentile mission (Library of New Testament studies), 29

19. A. J. B. Higgins, Jesus and the Son of Man (London, 1964), 34

20. R. Liechtenhahn, Die urchristliche Mission (Zurich, 1946), 40.

21. Hahn, Mission, 32

22. Three other incidents might have been included in this section on the actions of Jesus which affect the Gentiles. The first is the so-called northern journey of Jesus in Mk 7: 24 - 8: 36. However, we certainly cannot, with Spitta (Heidenmission, pp. iogf), make this journey the basis for calling Jesus the firs Christian missionary, since Jesus clearly made no attempt to preach to the inhabitants, who were at any rate partially, if not mainly,Jews.

23. Spitta, Heidenmission, 109

24. Jeremias, Promise, 63 